NBER WORKING PAPER SERIES

\title{
URBAN POVERTY, SCHOOL ATTENDANCE, AND ADOLESCENT LABOR FORCE ATTACHMENT: SOME HISTORICAL EVIDENCE
}

\author{
Howard Bodenhorn \\ Working Paper 12043 \\ http://www.nber.org/papers/w12043
NATIONAL BUREAU OF ECONOMIC RESEARCH 1050 Massachusetts Avenue
Cambridge, MA 02138
February 2006

Professor of Economics, Lafayette College, Easton, PA 18042 and Research Associate, National Bureau of Economic Research, Cambridge, MA. e-mail address bodenhoh @ lafayette.edu Phone 610-330-5308; fax 610-330-5715. Financial support from the National Science Foundation (SES-0109165) and the Earhart Foundation is gratefully acknowledged. The views expressed herein are those of the author(s) and do not necessarily reflect the views of the National Bureau of Economic Research.

(C2006 by Howard Bodenhorn. All rights reserved. Short sections of text, not to exceed two paragraphs, may be quoted without explicit permission provided that full credit, including $\odot$ notice, is given to the source. 
Urban Poverty, School Attendance, and Adolescent Labor Force Attachment: Some Historical

Evidence

Howard Bodenhorn

NBER Working Paper No. 12043

February 2006

JEL No. I1, I3, N3

\begin{abstract}
$\underline{\text { ABSTRACT }}$
It is well known that children raised in poverty demonstrate lower academic achievement than children raised in affluence. This study extends previous studies in three ways. First, it estimates structural instead of reduced-form models of child academic attainment. Such structural models explicitly account for choices made by children themselves, given choices made by parents and governments. Second, it provides an historical insight into the connections between poverty, child choices and educational outcomes. Nearly all extent work considers the late 20 th century. This study uses a unique data set from the mid-nineteenth century. And, third, this study documents the choices underlying adolescent labor force participation. Youth in poor households are more likely than affluent youth to be asked to contribute income to the household. The choice to do so is influenced by parental choices and the expected reduction in the child's later-life wealth attributable to choosing work over additional schooling.
\end{abstract}

Howard Bodenhorn

Department of Economics

110 Williams Simon Center

Lafayette College

Easton, PA 18042-1776

and NBER

bodenhoh@lafayette.edu 


\section{Urban Poverty, School Attendance, and Adolescent Labor Force Attachment}

Despite waging a "war on poverty" in the 1960s, about one-fifth of all US children and youth younger than 18 years continue to live in poverty. Nearly one-third of blacks and Hispanics under 18 years live in poverty (Proctor and Dalaker 2003). And the costs of poverty are high. Children raised in poverty are less healthy, demonstrate less emotional well-being, are more likely to experience a teenage birth, and complete fewer years of school than children from more affluent families (Brooks-Gunn and Duncan 1997; Duncan and Brooks-Gunn 1997; Seccombe 2000). The last result is particularly troubling because education is one of the more important childhood attainments. Not only is education key to lifetime economic success, but higher levels of education are associated with more efficient consumption choices, higher levels of happiness and self-esteem, and other measures of well-being (Haveman and Wolfe 1995). For these reasons alone identifying the determinants of a child's educational attainment is important.

One unresolved issue is whether the lesser observed outcomes for poor children are due to poverty per se, or do they result from other features of poor children's environments. Poor households, for example, are more likely to be headed by a single parent, a parent with low educational attainment, an unemployed parent, a parent laboring in a low-wage, low-prestige job, and a young parent (Brooks-Gunn, Duncan and Maritato 1997). They are also more likely to live in neighborhoods with fewer employment opportunities, higher crime rates, and lower levels of social capital (Wilson 1987). Unless these other features of the poor child's environment are 
controlled for, the consequence of poverty per se is indeterminate. Most studies, notably a series of replication studies employing different data sets reported in Duncan and Brooks-Gunn (1997), include a large number of additional correlates, including family structure and neighborhood effects, and the reduced-form models reported therein generally reveal that poverty influences children's attainments even after family and neighborhood influences are controlled for.

Haveman and Wolfe (1995) and Haveman, Wolfe and Wilson (1997), however, argue that a deeper understanding of causality depends not on the addition of more controls to reducedform models, but from the estimation of structural models. Unlike the traditional reduced-form model, a structural model can explicitly incorporate multiple lines of causality and better measure direct and indirect effects. This study employs a structural approach comparable to that used by Haveman, Wolfe and Wilson.

A second unresolved issue is whether the historical experience differed from the modern experience. Official poverty statistics were not generated prior to 1959, at which time 27 percent of children lived in poverty. In addition, nearly every study of the consequences for poverty on children's attainments makes use of one of the large cross-sectional or longitudinal data sets collected after $1957 .^{2}$ This study offers a unique insight into the historical connection between household poverty and schooling.

Data collected from the 1860 US federal census reveal that household poverty was associated with lower school attendance at all ages, but had a particularly negative effect on school attendance during the nineteenth-century's prime school ages of 9 to 13 years. Moreover,

\footnotetext{
2 The earliest of the data sets used is the Wisconsin Longitudinal Study, which collected data on Wisconsin
} 
the negative consequences of poverty persist even when the estimated structural models control for family structure, race and ethnicity, and neighborhood effects. Thus, in replicating the methods of modern studies, this study reveals the negative consequences of poverty on child outcomes in an historical context. It also shows that the negative consequences of poverty on children's academic achievement were strongest among children aged 9 to 13 years, which differs from modern studies that tend to find that poverty matters more during adolescence than childhood. This may be an artifact of modern mandatory attendance laws, which reduces school attendance pricipally among children older than the mandatory limit.

Finally, this study documents the incidence of early labor force participation among poor and nonpoor adolescent youth. Approximately one-fourth of all youth 14 to 16 years participated in the labor market in some fashion, but the participation rate of poor youth was about twice that of more affluent youth. Although adolescent labor added income to poor households and mitigated some of the effects of poverty, adolescent income contributed to the household may have come at the expense of higher potential earnings later in life had the teen attended school rather than entered the labor force.

\section{Conceptual apparatus}

The most commonly employed model of the connection between parental poverty and children's low academic achievement is Becker's (1981) model of the economics of the family. According to Becker, families allocate resources between current consumption and investments in children's human capital. A larger share of a poor family's budget will be expended on current 
consumption, leaving relatively less for human capital investment. The consequence is low academic achievement by children living in poor households.

Haveman and Wolfe (1995) and Haveman, Wolfe and Wilson (1997) offer a natural extension of Becker's theory, which still treats the family, especially parents, as pivotal. But in the extended model, the public sector influences choice through myriad policy instruments, including the provision of public schools and their financing, mandatory attendance laws, and so forth. Public policy establishes the basic institutional environment in which parents and youth make choices. $^{3}$

In addition to public and parental choices, the Haveman, Wolfe and Wilson model holds that children and youth make some decisions for themselves conditional on public and parental choices, and many such decisions will have important effects on their own achievement. A child's choices concerning engagement in schoolwork and smoking, sports and sex, or drama club and drugs will have enormous consequences for later life attainment. Thus, this comprehensive rational choice-based approach views choices by all three actors - government, parents and children -- as important determinants of children's success.

Following Haveman, Wolfe and Wilson's (1997) the approach adopted here assumes that a child's or youth's decision to spend additional time in school is determined by the expected rewards associated with additional attendance. ${ }^{4}$ The rewards from attendance take various forms,

${ }^{3}$ Goldin and Katz (2000) provide a valuable insight into how community and peer characteristics influence policy that, in turn, influences parental and student attitudes toward attendance.

${ }^{4}$ For children at younger ages, the model can incorporate choices made by parents and we will assume that the parental choices will be made based on the same calculus that would be used by students. In other words, at younger ages assume that parent's are well informed about their child's preferences. 
but it is assumed that they can be summarized in the expected value of some measurable economic variable, perhaps income or wealth, at some point in their adult life. Child n's objective function is to maximize expected utility:

$$
\mathrm{EU}^{*}{ }_{\text {in }}=\mathrm{EU}\left(\mathrm{W}_{\mathrm{in}}, \mathrm{Z}_{\mathrm{n}}\right)
$$

subject to the relevant constraints, where $\mathrm{W}_{\text {in }}$ represents a vector of random lifetime wealth outcomes, with density function $\mathrm{f}\left(\mathrm{W}_{\text {in }}\right)$, resulting from selecting educational level i. $\mathrm{Z}_{\mathrm{n}}$ represents a vector of past choices of the child, family and society that shape the economic opportunities open to child $\mathrm{n}$ prior to child n's decision to pursue additional education.

The child chooses educational outcome i only if the expected payoff of choice $\mathrm{i}\left(\mathrm{W}_{\mathrm{in}}\right)$ exceeds that for option $\mathrm{j}$ for all $\mathrm{i} \neq \mathrm{j}$. If we posit that the expected utility of alternative $\mathrm{i}$ can be characterized as:

$$
\mathrm{U}_{\mathrm{i}}=\beta_{1} \mathrm{Z}_{\mathrm{n}}+\beta_{2} \mathrm{E}\left(\mathrm{W}^{*} \mid \mathrm{X}, \mathrm{i}\right)+\epsilon_{\mathrm{i}}
$$

So that the child understands that $\mathrm{W}^{*}$ depends on the enrollment choice and believes that $\mathrm{W}^{*}$ also depends on a realization of an unobserved random vector $\mathrm{X}$, where $\mathrm{X}$ depends on prior choices made by the child, his or her family, and society. Thus, the probability of a child choosing alternative $i$ equals:

$$
\operatorname{Pr}_{i}=\operatorname{Pr}\left[e<\beta_{1} Z_{n}+\beta_{2}\left\{E\left(W^{*} \mid X, i\right)-E\left(W^{*} \mid X, j\right)\right\}\right] \text {, for all } i \neq j \text {, where } e=\epsilon_{i}-\epsilon_{j} \text {. }
$$

Following such a structural approach, estimates of the effects of poverty on school attendance are generated from a two-stage model. The first stage estimates the net present value of the difference in economic outcomes $\left\{\mathrm{E}\left(\mathrm{W}^{*} \mid \mathrm{X}, \mathrm{i}\right)-\mathrm{E}\left(\mathrm{W}^{*} \mid \mathrm{X}, \mathrm{j}\right)\right\}$. Data for the children's parents are used to calculate the expected net present value of additional schooling, using a subset of variables capturing parental and community choices and that are typically included in 
reduced-form models. Coefficients from the estimated "parent" model are then multiplied by the children's characteristics to obtain the child's estimate of the future payoff from choosing option i over option $\mathrm{j}$. At the second stage, the predicted value of $\left\{\mathrm{E}\left(\mathrm{W}^{*} \mid \mathrm{X}, \mathrm{i}\right)-\mathrm{E}\left(\mathrm{W}^{*} \mid \mathrm{X}, \mathrm{j}\right)\right\}$ is included as a separate regressor, in addition to child, family, and community characteristics to capture the child's expected payoff to his or her choice to attend school.

This procedure assumes that children form their expectations about economic opportunities by observing the realized outcomes of adults that resemble them in several dimensions, notably, race, ethnicity, and neighborhood of residence. ${ }^{5}$ Based on their observations concerning the payoff to greater literacy, children will choose to enroll or not. Given that the data set used here is not as rich as many modern longitudinal data sets, the model is limited to conditioning the child's choice on the payoff to basic literacy (choice i) or illiteracy (choice j). Whereas Haveman, Wolfe and Wilson generate conditional predictions of early adult incomes to investigate the responsiveness of a child's graduation decision, I use census data on household wealth to generate conditional predictions of household wealth at age 30, appropriately discounted to each child's age, to investigate the responsiveness of children's decision to attend school.

In addition to school attendance, I investigate whether early labor force participation was influenced by an adolescent's expectations about the later-life benefits of literacy, after controlling for other features of the household. Forward looking adolescents would consider the

${ }^{5}$ Borjas (2000) shows that neighborhood effects can be important determinants of later life outcomes, especially for immigrants and members of ethnic enclaves. However, Sanbonmatsu et al. (2006) find that movement away from poverty-stricken neighborhoods and poor schools has little measurable effect on the academic attainment of poor children. As such, their results suggest that household poverty per se matters, independent of community 
opportunity cost of attending school relative to entering the workforce. The rational adolescent would choose to enter the labor force when the appropriately discounted incremental benefit of additional time in school is less than the current value of foregone earnings. It is likely, however, that residence in a poor household, all else constant, will lead to higher rates of adolescent labor force participation. In effect, poverty raises the youth's discount rate and pulls poor youth into the labor force earlier than children living in wealthier households.

\section{Data and variables}

The effects of poverty on school attendance and adolescent labor force participation are studied using data drawn from the population manuscripts of the 1860 US federal census for Baltimore, Maryland and New Orleans, Louisiana. The choice of these two cities was determined by two factors. First, the data were originally drawn for a study of educational attainment among free blacks and Irish immigrants in the US South, so the data were drawn from two large southern cities in 1860 . Second, by the mid-nineteenth century every southern state, except Maryland and Louisiana, prohibited the education of free blacks (Woodson 1968). Hence the

focus on the youth educational experiences of two cities that allowed black attendance and, therefore, with economically and racially diverse students.

Given the original purpose of the sample, it includes an oversample of households headed by free blacks and Irish immigrant householders. Information on the characteristics of every African-American child between 6 and 16 years was collected and recorded. Such information includes the child's age, complexion (black or mulatto), state of birth, whether the child had factors.. 
attended school in the past year, and the child's occupation if he or she was employed. In addition to information on the children, data was collected on the household head, including his or her age, sex, place of birth, occupation, the value of household wealth, and literacy.

A comparable sample of white children was drawn from the censuses of Baltimore and New Orleans, with an oversample of children of Irish immigrants for Baltimore. The same information was collected and household status was defined and assigned in the same manner used for black children (see appendix for details). Households headed by native-born whites were randomly selected to provide a sample of similar size and neighborhood composition as the African-American sample. If 100 African-American households were found in Baltimore's first ward, approximately 100 white households from Baltimore's first ward were randomly selected. The final usable sample contains data on 4,561 African-American and 6,133 white children between ages 6 and 16 years, inclusive. Given the oversampling of blacks and children of Irish descent, statistics are weighted based on the probability of a household being drawn. And because the sample of children was not independent of household of residence, all reported standard errors are corrected for the statistical clustering of observations.

\section{School attendance}

Maryland prohibited black children from attending publicly funded schools, even though they paid taxes toward the support of such schools. Maryland did not, however, prohibit black children from attending private or parochial schools. Several charity schools and academies were provided by churches, concerned whites, and by blacks themselves. Well-to-do and middling 
black families sent their children to the several private schools willing to accept them. ${ }^{6}$ Louisiana allowed black children to attend its public schools, but negative white attitudes pushed most blacks into private and parochial schools.

The 1860 census has advantages and disadvantages for the study of nineteenth-century school attendance. The principal disadvantage is that census enumerators only asked whether an individual had received any instruction at any time during the past year, whether at a public school or private academy, or with tutor. Children and youth whose educations were limited to Sunday schools were not to be recorded as having been "at school." Given the question asked by enumerators, there is no way to determine whether the child attended regularly, intermittently, or even just once during the past year. Comparing state enrollment reports to the attendance figures from the 1910 census, which asked a comparable question, Moehling (2004) concludes that a positive response is best interpreted as irregular attendance. Margo (1990), on the other hand, suggests that a positive response in late nineteenth-century censuses is indicative of regular attendance. Some limited evidence from antebellum Maryland suggests that reported attendance is probably best viewed as occasional attendance. An 1860 Maryland legislative document reported that less than 50 percent of eligible children attended regularly, so that the data provide an upper bound to regular attendance (Shannon 1964). The exclusion of Sunday school instruction, on the other hand, may lead to underestimates of school attendance, especially for

\footnotetext{
${ }^{6}$ Advertisements published in the Baltimore American (3 August 1850; 8 September 1851) suggest that even families from the middling sorts could afford private education. One academy charged $\$ 40$ per year, payable in quarterly installments, for elementary education for adolescent youth. Children under 10 years paid $\$ 20$; those between 10 and 12 paid $\$ 25$. A girl's academy charged $\$ 20$ per annum for elementary instruction and between $\$ 40$ and $\$ 60$ for more advanced instruction.
} 
black children. Although Sunday schools focused on religious instruction, church schools often provided blacks with some remedial instruction.

\section{Poverty}

One advantage of the 1860 census relative to other federal censuses is that it is one of two that collected detailed information on household wealth. Although modern official poverty statistics are based on household income, a growing number of researchers argue that poverty is better defined by wealth, or a combination of wealth and income, than by income alone (Oliver and Shapiro 1995; Conley 1999; Shapiro 2004). Wealth provides a buffer against temporary income shocks, so that children in households with accumulated wealth will suffer fewer of the negative consequences of poverty if the household can offset its temporary (income) poverty by drawing on stocks of wealth to maintain current consumption and investments in children's human capital.

Making a virtue of necessity, this study adopts wealth as the principal basis for several alternative definitions of poverty. The issue is constructing an historically meaningful wealthbased poverty standard. Soltow (1975) adopts $\$ 100$ as the cutoff. He justifies his $\$ 100$-criterion because it is consistent with the ownership of two horses or 80 acres of land at the official government price of $\$ 1.25$ per acre. It was also about one-fifth of average annual income in 1860. Oliver and Shapiro (1995, p. 71) would note that the last criterion is the most relevant. They offer one definition of "not poor" as having household wealth equal to about two months of middle class spending, which would equal \$81 with average household income of \$500 in 1860 . 
Soltow further defends his $\$ 100$ standard by noting that about five in eight adult male householders held more than $\$ 100$ in 1860 . By this standard he adopts the $38^{\text {th }}$ centile as the poverty standard. As an alternative to Soltow's $\$ 100$ measure, this study adopts a second poverty standard of the lowest wealth quintile. The cutoff for the lowest wealth quintile among those households reporting any wealth is $\$ 50$, which is the second poverty criterion used in the empirical analysis. ${ }^{7}$

The $\$ 50$ and $\$ 100$ poverty cutoffs assume that the effects of poverty would be discontinuous at some predetermined, if justifiable point. One lesson that emerges from several studies is that the effects of poverty are not fully captured with the use of continuous variables (wealth or income) or by including a single dummy variable representing a discontinuity at some point (see Duncan and Brooks-Gunn 1997). Instead, modern studies typically include several dummy variables representing multiples of the income-to-needs ratio. I adopt a comparable practice. A third measure of poverty defines the very poor as those households in the lowest wealth decile (wealth $\leq \$ 10$ ); the poor as those above the lowest decile, but below the lowest quartile $(\$ 10<$ wealth $\leq \$ 30)$; the near-poor as those households with wealth greater than the lowest quartile but below the median $(\$ 30<$ wealth $\leq \$ 200)$.

As a further robustness check, three alternative measures of poverty include whether the household owned its own home; whether the head of the household was employed in a lowstatus occupation (see appendix for details); or whether the head of the household was employed as a common laborer. Home ownership may capture some aspect of well-being - residential

\footnotetext{
7 The data appendix details the procedure used to impute wealth when household wealth was unreported.
} 
stability, for example - not captured in the other wealth measures. Low job status and employment as a laborer are included to proxy for income poverty as opposed to wealth poverty. Finally, the empirical analysis reports results on any possible wealth composition effects, so that the independent effects of home ownership and being in the very poor, poor, and near-poor categories based on its holdings of personal wealth. Each of the five definitions captures a different aspect of poverty and while each tells us something different about the nature of poverty, the empirical results are robust to alternative definitions.

Table 1 reports the means for several variables for all children between 6 and 16 years, inclusive, and then separated according to the $\$ 50$ wealth criterion. The first panel of the table provides summary statistics for children according to the definitions of poverty. Depending on the definition, between 15 percent (common laborers) and 45 percent (very poor and poor) of children lived in poverty. About 25 percent of all children lived in an owner-occupied dwelling, but no poor children did. In addition, children living in wealth-poor households were more likely to live with parents who labored at low-status, low-wage occupations and were, thus, more prone to income-poverty as well.

The second panel provides summary evidence on school attendance. According to Vinovskis (1983) the prime school attendance ages at mid-century were 9 to 13 years. She argues that the social norm of sending younger children to school was not yet well established; nevertheless, more than half of children ages 6 to 8 attended school. Attendance fell by half after age 13. The data also reveal that boys and girls attended school at nearly equal rates. So what did adolescents not attending school do with their time? The third panel reveals that some of them participated in the labor force. Approximately one-fourth of boys and one-tenth of girls ages 14 
to 16 were engaged in some market labor. The statistics also reveal that child labor was uncommon. Not a single girl between 6 and 8 years was employed, and only a minuscule fraction of boys or girls between 9 and 13 years were employed. Teen labor force participation among adolescents was also about twice that among the poor as among the nonpoor.

The final two panels of Table 1 provide statistics on the sex, race, ethnicity, and family structures of the sample. About 10 percent of the [weighted] sample is African American; about 16 percent of children had parents born in Ireland, more than one-fourth had parents of German heritage, and another 10 percent were immigrants from other places, principally England and Scotland. Finally, about 10 percent of children lived with a single parent and, as in modern studies, children residing with single mothers are somewhat more likely to live in poverty. Unlike modern studies, single fatherhood was as common as single motherhood. Mortality rates were high at mid-century and orphanage (residing with neither parent) was an equal opportunity condition. About 3 percent of poor and nonpoor children resided with neither parent.

\section{Poverty and school attendance: Structural estimates}

Although summary statistics are informative, they do not control for the multiple influences on school attendance. This section estimates structural models of school attendance for children and youth of three separate age cohorts (6 to 8 years; 9 to 13 years; and 14 to 16 years), reflecting age related differences in attendance attributable to contemporary social attitudes toward attendance. The structural models are estimated in two steps. In the first step (not reported for brevity), the predicted value of household wealth is estimated using parents' characteristics. The left hand side variable is household wealth and the right-hand side regressors 
include the head of the household's age and its square; the head's sex, race and ethnicity; the city of residence; and census ward. The right-hand variable of greatest interest, however, is the head's literacy.

Using the estimated coefficients from the parent regressions, two predicted values of a child's wealth at age 30 are estimated, one based on an assumption that the child attained literacy, and a second with the contrary assumption. The present value of the difference is then calculated for each child based on his or her age using a 6 percent discount factor. ${ }^{8}$ Estimates of the discounted value of the future literacy-illiteracy wealth differential are then included as a separate regressor in the second stage. The second-stage regressions are estimated as probit regressions where the dependent variable is the dichotomous school attendance choice variable (1 = attended school).

Tables 2 through 4 report the predicted marginal effects on the relevant poverty variable, as well as the anticipated wealth differential, for seven separate specifications. Each specification includes controls for family structure; sex, race and ethnicity; and city and census ward effects, which were jointly significant in nearly all specifications.

Table 2, for example, reports the results for children aged 6 to 8 years. In model (1) young children living in households with less than $\$ 50$ in total wealth were about 6.5 percent less likely to attend school than children living in more well-to-do households, holding all else constant. For young children the expected differential in wealth at age 30 accruing to literacy

\footnotetext{
8 The six percent estimate is a bit higher than typical long-term antebellum interest rates reported in Homer and Sylla (1991). The choice to use slightly higher rates is consistent with the impatience of youth. Ultimately, the choice of discount rate is not of great importance given the assumption that all individuals discounted the future at the same rate. I can think of no reasonable method to identifying those children who may have had higher or lower
} 
was also an important determinant of school attendance. The estimated poverty effect using the $\$ 100$ cutoff is about the same as that estimated for the $\$ 50$ cutoff. (The estimated effects for older children are comparable to and consistent with those estimated for younger children and are discussed in greater detail only selectively.)

Model (3) reveals discontinuities in the effects of poverty based on the depth of poverty. Children 6 to 8 years living in very poor households were about 15 percent less likely to attend school than children living in wealthy households (those in the top quartile of the wealth distribution). Young children living in poor households were about 9 percent less likely attend school; and children living in near-poor households were about 6 percent less likely to attend school. The estimated coefficients for the very poor and poor are not significantly different from one another; neither are the poor and near-poor coefficients. The very poor and near-poor are, however, significantly different from one another. A similar result holds for children aged 9 to 13 years. The pattern for adolescents differs from that for younger children. Among adolescents, those living in the poorest households are somewhat more likely than children living in poor or near-poor households to attend school. It is possible that these very poor children took advantage of charity schools established in the mid-nineteenth century to serve the truly indigent. But without additional information, we are left to speculate about the social, parental and child choices underlying this curious result.

Model (4) captures wealth effects by including a dummy variable if the household reported a positive value for real estate, which is taken to imply home ownership. Home ownership had no significant effect on attendance by the youngest children, but had large

discount factors. 
positive influences on attendance by older children and adolescents. Home ownership increased school attendance by an estimated 5 percent for 9 to 13 year-olds and by 9 percent for adolescents. Home ownership may be capturing two effects, one of which is wealth. Home ownership may also be capturing what may best be labeled stability effects. Home ownership may represent a commitment to a community or neighborhood and the development of networks and social capital inherent in establishing a permanent residence. To investigate this possibility Model (7) includes home ownership as well as categories for very poor, poor and near-poor. Once we include the additional wealth measures, the positive effects of home ownership disappear for pre-adolescent children. For adolescent children, however, the home ownership effect partly offsets the negative poverty effects on school attendance. It is well known that adolescents are at higher risk than younger children for self-defeating behavior and it appears that home ownership, which may proxy for residential stability, may reduce some of the negative consequences of poverty among youth. This is a hypothesis worthy of further study.

Models (5) and (6) are included to investigate the potential effects of income poverty, instead of wealth poverty, by including proxies for low-income households. Model (5) defines poverty as household heads employed in low status occupations. Children residing in households headed by an individual employed in a low-status occupation are about 4 percent less likely to attend school than children living in a household headed by an individual with higher status occupations. Model (6) reports the marginal effect on school attendance for children residing in a household headed by an individual whose listed occupation was laborer or day laborer. 
Compared to households headed by an individual with an unknown occupation, the children of laborers were 0 to 6 percent less likely to attend school, depending on age. ${ }^{9}$

What comes out of all these models is that poverty lowers school attendance, which is not a surprising result given that many modern studies find comparable results. The results do, however, show that wealth poverty is just as important as income poverty in reducing school attendance. Interestingly, home ownership tends to offset, in part, the negative consequences of poverty for school attendance. The connection between real estate ownership and increased school attendance merits further study because it tends to hold even when poverty is controlled for in other dimensions.

In addition to the effects of poverty, a second important focus of this study is to understand the structural effects of anticipated differences in lifetime earnings or wealth and their effects on the choice to attend school. According to the estimated coefficients a one standard deviation increase in the expected discounted wealth differential raised the likelihood of attending school by 4.6 percent for young children (ages 6 to 8), holding all else constant (see Table 2). This result holds regardless of the definition of poverty employed. An interesting result is that the size of the effect declines as children age. For children between 9 and 13 years, the effect of a one standard deviation change in the estimated wealth differential is an average of 1.3 percent across the seven models. For adolescents, the estimated effect of a one standard deviation increase in the return to literacy elicits an increased probability of attendance between 0.5 and 1.2 percent, with an average effect across all seven models of 0.9 percent.

\footnotetext{
${ }^{9}$ The regression also includes dummy variables for household heads employed in professional, managerial,
} 
How might this age-dependent wealth differential result be explained? It is fully consistent with diminishing marginal returns to additional education at older ages. For young children with little prior schooling, the expected payoff to additional school attendance is substantial. An increase in the expected discounted value of wealth at age 30 of just $\$ 152$ (or one standard deviation) associated with attaining basic literacy (mean estimated wealth at age $30=$ \$2962) was enough to elicit a relatively large increase in school attendance. As we observe children at consecutively older ages, however, it is likely that a growing percentage of them have already made some strides toward literacy. For these children the expected payoff to additional education is smaller, which elicits a smaller percentage increase in enrollments for a given anticipated discounted change in later-life wealth. Not surprisingly the later-life wealth effect is smallest for the oldest children observed in this sample. Thus, children (and/or their parents making decisions on their behalf) were responding rationally to the incentive effects of additional school attendance. The anticipated incremental benefit was largest at younger ages, which elicited the greatest behavioral response for children at younger ages. Note that older children responded positively to the later-life wealth incentive as well, but because they were likely to have already acquired some basic skills their responses were less pronounced.

\section{Poverty and early labor force participation}

Statistics reported in Table 1 reveal notable differences in labor force participation for poor and more affluent adolescents. Indeed, poor adolescents participated in the labor market at approximately double the rate of more affluent adolescents. This section explores the 
determinants of early labor force attachment using the same structural model used to investigate differences in school attendance. Because only a very small fraction of children under 14 years engaged in market-oriented labor, this study considers only the adolescent experience.

Table 5 reports the results of seven estimated models that correspond to those estimated in the previous section. The dependent variable is a dummy variable equal to one if the youth reported any type of labor market employment to the census marshal and zero otherwise. As in the previous section, there are two variables of interest. The first, of course, are the various measures of poverty, which provide some insight into the question: What were the marginal effects of household poverty on early teen labor force participation? The second question centers on the issue of opportunity cost and teen choices toward work. Working typically meant not attending school, even among teen apprentices who contracted for education in their indentures (Watkinson 1996). Securing employment, earning income and contributing to the household implied lower levels of academic attainment and potentially lower levels of basic literacy. The cost of starting work early was fewer years of schooling, lower literacy, and lower long-term earnings capacity. How did this tradeoff influence youth choices toward work and school in the mid-nineteenth century? To answer this question, a two-stage or structural model is estimated. The first stage model is the same described above, where differences in expected wealth (properly discounted) at age 30 due to differences in literacy are predicted for each youth. This prediction is then included in the second-stage probit model where the student is modeled as choosing between working and not working.

Model (1) in Table 5 shows that adolescents residing in a household with less than $\$ 50$ in total gross wealth were about 3.5 percent more likely to be employed than adolescents living in 
households with more than $\$ 50$ in wealth. When the poverty cutoff is increased to $\$ 100$, children living in these poor households are about 7.5 percent more likely to be engaged in marketoriented labor. Model (3) again provides for more than one discontinuity in the effects of poverty depending on the depth of household poverty. The marginal effects were effectively equal for all three levels of poverty (i.e., very poor, poor and near-poor), such that living in an impoverished household increased the likelihood of working by about 9 percent. Home ownership decreased the likelihood of engaging in work. When we include both home ownership and the dummy variables for three levels of poverty, poverty continues to have a significantly positive effect on adolescent employment, while the home ownership effect is still negative but is small and statistically insignificant. Finally, income poverty, proxied by low-wage and low-status occupations, has no statistical effect on adolescent labor force participation. Decisions toward adolescent employment appear to depend more on wealth poverty relative to income poverty - a finding consistent with Oliver and Shapiro (1995) and Conley (1999) who argue that wealth gaps are now as important as income gaps in influencing household outcomes.

Given the potential tradeoff between working and attending school among adolescents, each of the seven models includes the discounted estimated wealth differential for each youth. This variable is designed to capture the forward-looking effects of wealth gaps resulting from foregoing additional school in order to work and earn an income. In every model, the estimated marginal effect of a one standard deviation increase in the long-run cost of illiteracy decreases labor force participation among adolescents by an estimated 1.5 percent, after controlling for poverty and other personal, familial and neighborhood influences. The poverty effects are clearly larger in magnitude than the long-term wealth effect, but the results make it clear that 
adolescents did weigh the costs and benefits of early labor force participation and that the greater the cost of working (or not attending school), the less likely an adolescent was to enter the labor force.

\section{Concluding comments}

The preceding analysis lends support to Haveman, Wolfe and Wilson's (1997) contention that a better understanding of child and youth behavior must take into account choices made by the children themselves. Childhood poverty, as would be expected, had a negative influence on children's academic achievement. Children living in poverty in the mid-nineteenth century were significantly less likely to attend school than children living in more affluent households. Similarly, poor youth were more likely to enter the labor force than nonpoor youth.

Two larger findings also emerge from this study. First, poverty defined by wealth is an equally, sometimes more, important determinant of childhood outcomes than income. Oliver and Shapiro (1995) and Conley (1999) have emphasized the growing importance of wealth gaps in determining a number of social and economic outcomes. This research confirms that wealth was also an important determinant of child and youth outcomes 150 years ago. Second, it reveals that reduced-form models, while capable of highlighting important aspects of the poverty-schooling nexus, do not fully capture the subtleties of that nexus. Structural models, like those advocated by Haveman, Wolfe and Wilson, explicitly incorporate choices made by parents and choices made by children on their own behalf. Children and, especially youth, are faced with myriad choices everyday, many of which will significantly influence their future earning capacity. This study, like Haveman, Wolfe and Wilson's, shows that youth are forward looking and make 
choices consistent with models of rational economic behavior. Foregoing school to engage in market-oriented work is likely to reduce future earnings and wealth if earnings and wealth are positively correlated with academic achievement and if work interferes with schooling.

Recognizing these connections, youth at mid-century facing greater payoffs to education were more likely to stay in school and less likely to enter the labor force as adolescents. Future work on the connection between poverty and childhood outcomes should more fully and explicitly investigate how student choices are influenced by expected future outcomes.

\section{Data appendix}

\section{Defining Household Structures}

Classifying children as residing in a female-headed household was trivial. Any child living in a household where the census enumerator recorded the household head as female was so recorded in the data. But because a female head might be a sister, a grandmother, or an unrelated female, an alternative scheme was adopted to separate single mothers from other types of female heads. If the child lived in a household with a female head and had a different surname than any adult in the household, he or she was classified as living with neither parent.

A child was classified as living with a single mother if the female head was related to the child (same surname) and at least 15 and no more than 49 years older than the child. ${ }^{10} \mathrm{~A}$ child was classified as living with a single father if the male head was not a member of a traditional family, was related to the child and he was at least 15 but no more than 49 years older than the child. A child was classified as

\footnotetext{
10 This scheme does not and cannot distinguish unmarried aunts from single mothers. It is assumed that the
} 
living in a two-parent household if first-listed male and first-listed female in the household were related to the child, if the first-listed female was no more than 15 years younger nor more than 20 years older than the first-listed male, and both parents were at least 15 but no more than 49 years older than the child. A child was classified as living with neither parent if his or her surname was different than both adults and all other children in the household. The classification schemes follow those used in coding the IPUMS.

A child was classified as residing in a traditional household, as an alternative the mechanistically defined two-parent household, if the household had all the outward appearances of a traditional family. Such households included two adults with the same surname followed immediately by one ore more children in descending order of age with the same surname as the married adults. This less precise measure was collected as a robustness check against the two-parent definition. Because the objective and subjective attributions return nearly identical results, we can be reasonably confident that we are indeed identifying two-parent households.

\section{Household Wealth}

Census enumerators were asked to solicit householders' estimates of the dollar value of the household's real and personal property. The value of the householder's estate was to exclude liens or the value of rental property. Thus, the reported figures are gross, not net, real estate wealth actually owned by the household. Estimates of personal property were also solicited from householders, and estimates were to encompass the value of all other property, including financial assets, slaves, livestock, jewelry, fixtures, and furniture. The instructions recognized that an accurate valuation might not be had, but marshals were encouraged to obtain as "near and prompt" an estimate as they could. The Census Bureau anticipated the reluctance of many householders to divulge information about their wealth and instructed marshals to cajole and reassure respondents that the information was confidential and would not be handed over to the

incidence of such households is low. 
tax authorities.

It is clear that some marshals were better at cajoling or reassuring householders than others. It was not uncommon for marshals to return a blank (nonresponse) when reporting real and personal estate in the manuscripts. An empty cell in the real estate column is generally taken to represent that the household rented its current habitation, but historians have long debated the meaning of blank cells in the personal property column. Some contend that marshals left the cells blank rather than recording zeroes. Others contend that marshals failed to report small or odd holdings, so that blank cells represent small, but nonzero, values. Conley and Galenson (1998) and Bodenhorn (2003) review the debate and the data and conclude that marshals had idiosyncratic, nonzero censoring points for personal wealth below which they returned a blank.

Just as there is no consensus on the interpretation of blank cells in the personal estate column, there is no consensus on how to handle the blanks empirically. Conley and Galenson (1998) and Bodenhorn (2003) employ quantile (median) regression techniques; others estimate Tobit specifications; still others impute a small nonzero value prior to taking the natural logarithm and estimating OLS specifications. Bodenhorn and Ruebeck (2005) estimate the model using the inverse hyperbolic sine specification, which does not require an imputation for zeroes. Some studies, such as Conley and Galenson (1998) found that results and interpretations may not be robust to alternative methods, but Bodenhorn and Ruebeck (2005) find their results to be robust to a wide variety of alternative specifications.

This study follows the Bodenhorn and Ruebeck strategy of imputing a ward-specific value for a household not reporting a value for personal estate equal to one-half the smallest value returned by any marshal in a given ward. The inclusion of ward dummy variables then corrects for some of the bias that may be introduced by following this procedure. In addition, robust standard errors are reported. A number of robustness checks were performed and the basic results stand regardless of imputation. This imputation 
method is chosen because it preserves sample size.

\section{Classification of Occupations}

Two additional types of variables are included to capture potential human capital or household resource effects on child outcomes. One variable (SEI) is a Duncan-style socioeconomic index of occupation prestige (Reiss 1961). The index is based on wages and educational levels associated with several hundred occupations reported in the 1950 census. Translating these values to the 1860 census is straight forward in some instances (e.g., blacksmith, barber, carpenter, bricklayer, minister, etc.), but some occupations listed in the 1860 census were obsolete by 1950 so that assigning them an SEI code required some ingenuity. There were, for example, no carriage drivers in 1950 except for a few in tourist locales. Carriage driving was a reasonably important occupation in 1860. But there is a modern analog to the carriage driver, namely, the taxi driver. Similarly, modern bus drivers are the analog to stagecoach drivers; and truckers to carters and draymen. When a specific 1860 occupation had no obvious analog to a 1950 employment, a Duncan SEI corresponding to industry (textiles, food, metals, servies, etc.) and broad job classification (laborer, operative, sales, manager, etc.) was assigned.

As an alternative to the SEI codes, all occupations were assigned one of eight industrial classifications: professional, managerial, sales, service, crafts, operatives, laborers, and agriculture. Dummy variables were then constructed for each of these broad occupational classifications. The results are typically robust to the continuous and dummy variable measures. 


\section{References}

Baltimore American, various issues, 1850-1851.

Becker, Gary S. 1981. A Treatise on the Family. Cambridge, Mass.: Harvard University Press.

Bodenhorn, Howard. 2003. "The Complexion Gap: The Economic Consequences of Color among Free African Americans in the Rural Antebellum South." Advances in Agricultural Economic History 2, pp. 41-73.

Bodenhorn, Howard and Christopher S. Ruebeck. Forthcoming. "Colorism and AfricanAmerican Wealth: Evidence from the Nineteenth-Century South.” Journal of Population Economics.

Borjas, George J. 2000. "Ethnic Enclaves and Assimilation." Swedish Economic Policy Review 7, pp. 89-122.

Brooks-Gunn, Jeanne and Greg J. Duncan. 1997. "The Effects of Poverty on Children." The Future of Children 7(2), Summer/Fall, pp. 55-71.

Brooks-Gunn, Jeanne, Greg J. Duncan, and Nancy Maritato. 1997. "Poor Families, Poor Outcomes: The Well-Being of Children and Youth.” In Consequences of Growing Up Poor, pp. 1-17. Edited by Greg J. Duncan and Jeanne Brooks-Gunn. New York: Russell Sage Foundation.

Conley, Dalton. 1999. Being Black, Living in the Red. Berkeley, CA: University of California Press.

Conley, Timothy G. and David W. Galenson. 1998. "Nativity and Wealth in Mid-NineteenthCentury Cities.” Journal of Economic History 27(1), March, pp. 149-165.

Duncan, Greg J. and Jeanne Brooks-Gunn (eds.). Consequences of Growing Up Poor. New 
York: Russell Sage Foundation, 1997.

Hauser, Robert M. and Megan M. Sweeney. 1997. "Does Poverty in Adolescence Affect the Life Chances of High School Graduates?” In Consequences of Growing Up Poor, pp. 541-95. Edited by Greg J. Duncan and Jeanne Brooks-Gunn. New York: Russell Sage Foundation.

Haveman, Robert and Barbara Wolfe. 1995. “The Determinants of Children's Attainments: A Review of Methods and Findings.” Journal of Economic Literature 33(4), December, pp. 1829-1878.

Haveman, Robert, Barbara Wolfe, and Kathryn Wilson. "Childhood Poverty and Adolescent Schooling and Fertility Outcomes: Reduced-Form and Structural Estimates." In Consequences of Growing Up Poor, pp. 419-460 . Edited by Greg J. Duncan and Jeanne Brooks-Gunn. New York: Russell Sage Foundation.

Goldin, Claudia and Lawrence Katz. 2000. "Education and Income in the Early Twentieth Century: Evidence from the Prairies," Journal of Economic History 60(3), September, pp. $782-818$

Homer, Sidney and Richard Sylla. 1991. A History of Interest Rates. New Brunswick, NJ and London: Rutgers University Press.

Margo, Robert A. 1990. Race and Schooling in the South, 1880-1950. Chicago: University of Chicago Press.

Mayer, Susan E. 1997. “Trends in the Economic Well-Being and Life Chances of America's Children.” In Consequences of Growing Up Poor, pp. 49-69. Edited by Greg J. Duncan and Jeanne Brooks-Gunn. New York: Russell Sage Foundation. 
Moehling, Carolyn M. 2004. "Family Structure, School Attendance, and Child Labor in the American South in 1900 and 1910.” Explorations in Economic History 41(1), month, pp. 73-100.

Oliver, Melvin and Thomas M. Shapiro. 1995. Black Wealth / White Wealth: A New Perspective on Racial Inequality. New York: Routledge.

Proctor, Bernadette D. and Joseph Dalaker. 2003. "Poverty in the United States: 2002." Current Population Reports, P60-222. Washington, D.C.: US Government Printing Office.

Reiss, Albert J. 1961. Occupations and Social Status. New York: The Free Press.

Sanbonmatsu, Lisa, Jeffrey R. King, Greg J. Duncan, and Jeanne Brooks-Gunn. 2006. "Neighborhoods and Academic Achievement: Results from the Moving to Opportunity Experiment." National Bureau of Economic Research Working Paper \#11909 (January).

Seccombe, Karen. 2000. "Families in Poverty in the 1990s: Trends, Causes, Consequences, and Lessons Learned." Journal of Marriage and the Family 62(4), November, pp. 1094-1113.

Shannon, William H. 1964. Public Education in Maryland (1825-1868) with Special Emphasis upon the 1860's. Unpublished Ph.D. dissertation, University of Maryland at College Park.

Shapiro, Thomas M. 2004. The Hidden Cost of Being African American: How Wealth Perpetuates Inequality. New York and Oxford: Oxford University Press.

Soltow, Lee. 1975. Men and Wealth in the United States, 1850-1870. New Haven and London: Yale University Press.

Taeuber, Karl E. and Alma F. Taeuber. 1965. Negroes in Cities: Residential Segregation and Neighborhood Change. Chicago: Aldine Publishing Company.

Vinovskis, Maris A. 1983. "Quantification and the Analysis of American Antebellum $-28-$ 
Education.” Journal of Interdisciplinary History 13(4), Spring, pp. 761-786.

Watkinson, James D. 1996. "Reluctant Scholars: Apprentices and the Petersburg (Virginia) Benevolent Mechanics Association School.” History of Education Quarterly 36(4), Winter, pp. 429-448.

Wilson, William Julius. 1987. The Truly Disadvantaged: The Inner City, the Underclass, and Public Policy. Chicago: University of Chicago Press.

Woodson, Carter G. 1968. The Education of the Negro prior to 1861. Washington, D.C.: Associated Publishers, Inc., 1919. Reprint Edition: New York: Arno Press. 
Table 1: Summary statistics for poverty and other household characteristics

\begin{tabular}{|c|c|c|c|}
\hline & All households & $\begin{array}{l}\text { Households with } \\
\text { wealth } \geq \$ 50\end{array}$ & $\begin{array}{l}\text { Households with } \\
\text { wealth }<\$ 50\end{array}$ \\
\hline \multicolumn{4}{|l|}{ Poverty } \\
\hline $\begin{array}{l}\text { Household } \\
\text { wealth }<\$ 50\end{array}$ & .261 & na & na \\
\hline $\begin{array}{l}\text { Household } \\
\text { wealth }<\$ 100\end{array}$ & .367 & na & na \\
\hline $\begin{array}{l}\text { VERY POOR } \\
\text { household }\end{array}$ & .167 & na & na \\
\hline $\begin{array}{l}\text { POOR } \\
\text { household }\end{array}$ & .282 & na & na \\
\hline $\begin{array}{l}\text { NEAR POOR } \\
\text { household }\end{array}$ & .265 & na & na \\
\hline $\begin{array}{l}\text { Home } \\
\text { ownership }\end{array}$ & .255 & .346 & .000 \\
\hline $\begin{array}{l}\text { Low status } \\
\text { occupation }\end{array}$ & .256 & .209 & .391 \\
\hline $\begin{array}{l}\text { Occupation = } \\
\text { Laborer }\end{array}$ & .153 & .113 & .268 \\
\hline \multicolumn{4}{|l|}{ School attendance } \\
\hline Boys 6-8 years & .555 & .570 & .514 \\
\hline Boys 9-13 years & .762 & .791 & .674 \\
\hline Boys $14-16$ years & .380 & .454 & .211 \\
\hline Girls 6-8 years & .593 & .632 & .483 \\
\hline Girls 9-13 years & .769 & .784 & .722 \\
\hline Girls $14-16$ years & .331 & .338 & .307 \\
\hline \multicolumn{4}{|l|}{ Labor force part. } \\
\hline Boys 6-8 years & .000 & .000 & .001 \\
\hline Boys 9-13 years & .007 & .003 & .021 \\
\hline Boys 14-16 years & .277 & .215 & .421 \\
\hline Girls 6-8 years & .000 & .000 & .000 \\
\hline Girls 9-13 years & .005 & .002 & .013 \\
\hline Girls $14-16$ years & .086 & .061 & .166 \\
\hline \multicolumn{4}{|l|}{ Sex/race/ethnicity } \\
\hline Male & .508 & .503 & .522 \\
\hline African American & .094 & .084 & .123 \\
\hline
\end{tabular}




$\begin{array}{llll}\text { Irish parents } & .165 & .161 & .174 \\ \text { German parents } & .263 & .247 & .310 \\ \text { Other immigrant parents } & .098 & .106 & .075 \\ \text { Family structure } & & & \\ \text { Single mother } & .090 & .083 & .111 \\ \text { Single father } & .096 & .094 & .100 \\ \text { Neither parent } & .035 & .035 & .034 \\ \text { Siblings 6-16 } & 1.66 & 1.73 & 1.47 \\ \text { Sibling 6-16 } & .612 & .646 & .517 \\ \text { attends school (0/1) } & & & \end{array}$

Notes: na $=$ not applicable

Sources: 1860 census population manuscripts for Baltimore, Maryland and New Orleans, Louisiana, see text and data appendix for details and definitions. 
Table 2: Structural estimates of poverty effects on school attendance for children 6 to 8 years of age marginal effects from unweighted Probit regressions

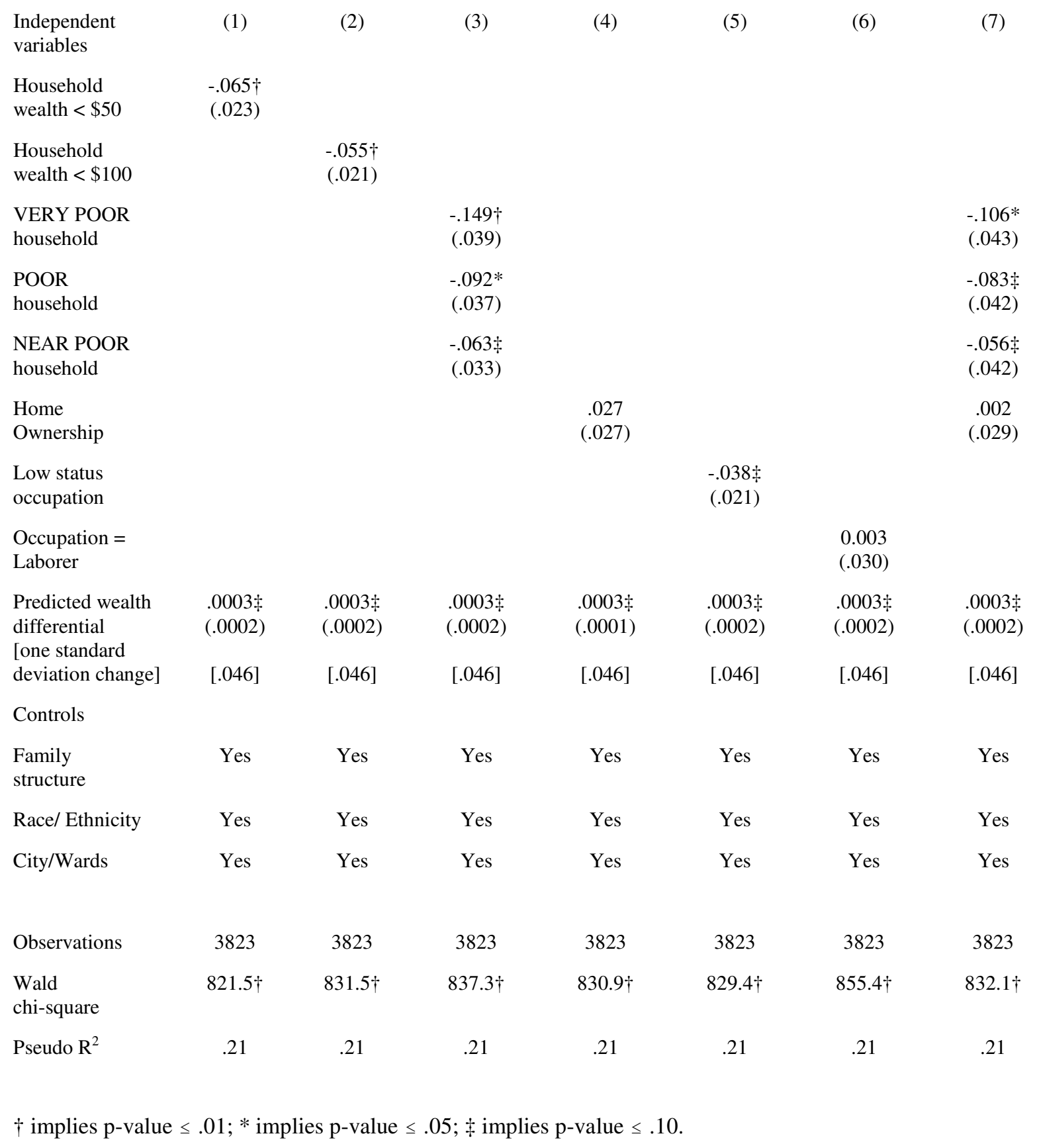


Table 3: Poverty and school attendance for children 9 to 13 years of age marginal effects from unweighted Probit regressions

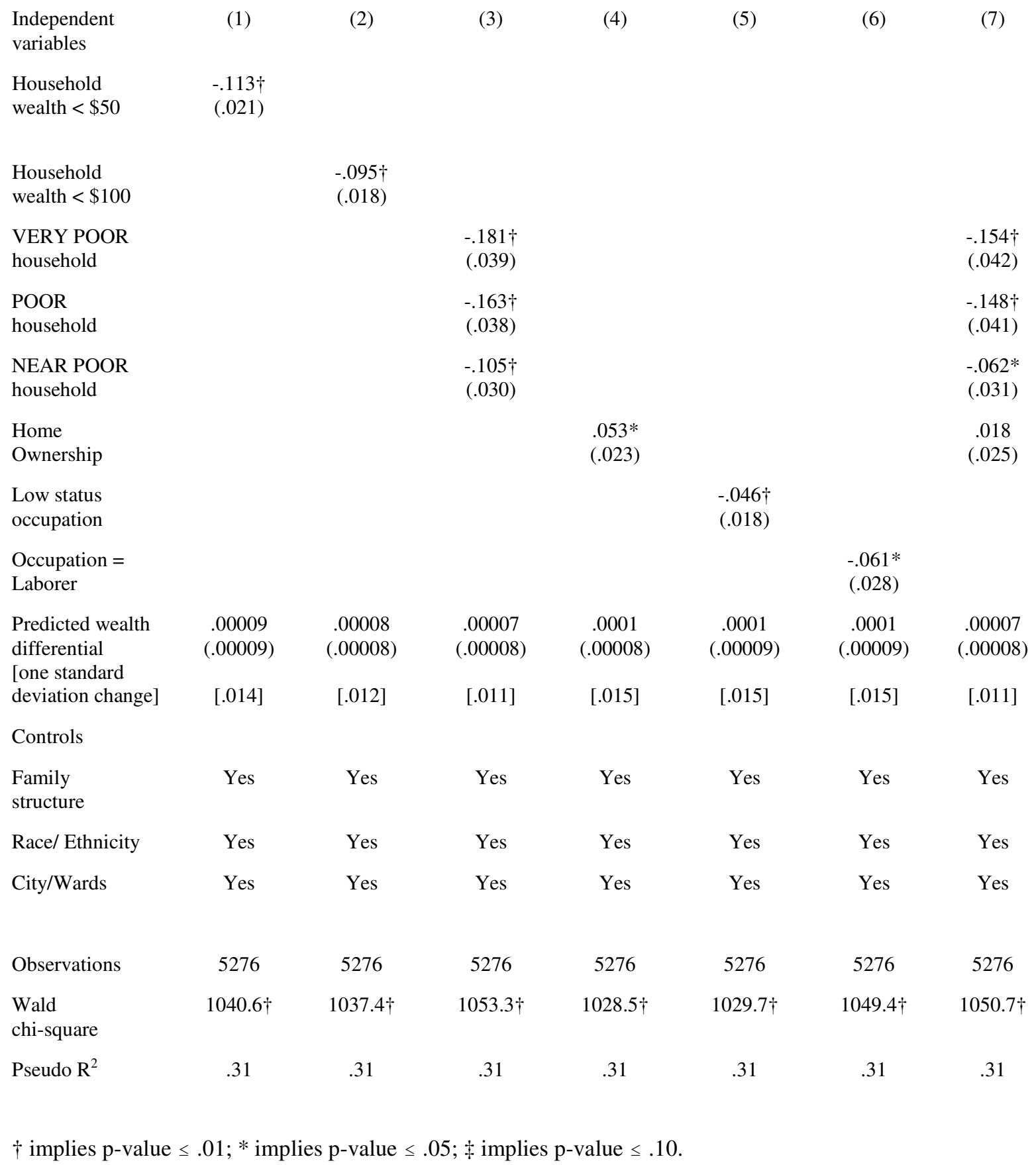


Table 4: Poverty and school attendance for youth 14 to 16 years of age marginal effects from unweighted Probit regressions

\begin{tabular}{|c|c|c|c|c|c|c|c|}
\hline $\begin{array}{l}\text { Independent } \\
\text { variables }\end{array}$ & (1) & (2) & (3) & (4) & (5) & (6) & (7) \\
\hline $\begin{array}{l}\text { Household } \\
\text { wealth }<\$ 50\end{array}$ & $\begin{array}{l}-.052 * \\
(.020)\end{array}$ & & & & & & \\
\hline $\begin{array}{l}\text { Household } \\
\text { wealth }<\$ 100\end{array}$ & & $\begin{array}{l}-.075 \dagger \\
(.018)\end{array}$ & & & & & \\
\hline $\begin{array}{l}\text { VERY POOR } \\
\text { household }\end{array}$ & & & $\begin{array}{r}-.088 \dagger \\
(.026)\end{array}$ & & & & $\begin{array}{l}-.088 \dagger \\
(.028)\end{array}$ \\
\hline $\begin{array}{l}\text { POOR } \\
\text { household }\end{array}$ & & & $\begin{array}{l}-.146 \dagger \\
(.019)\end{array}$ & & & & $\begin{array}{l}-.138 \dagger \\
(.021)\end{array}$ \\
\hline $\begin{array}{l}\text { NEAR POOR } \\
\text { household }\end{array}$ & & & $\begin{array}{l}-.144 \dagger \\
(.020)\end{array}$ & & & & $\begin{array}{l}-.163 \dagger \\
(.023)\end{array}$ \\
\hline $\begin{array}{l}\text { Home } \\
\text { Ownership }\end{array}$ & & & & $\begin{array}{l}.094 \dagger \\
(.023)\end{array}$ & & & $\begin{array}{l}.045^{*} \\
(.022)\end{array}$ \\
\hline $\begin{array}{l}\text { Low status } \\
\text { occupation }\end{array}$ & & & & & $\begin{array}{r}-.048 \dagger \\
(.018)\end{array}$ & & \\
\hline $\begin{array}{l}\text { Occupation = } \\
\text { Laborer }\end{array}$ & & & & & & $\begin{array}{l}-.045 \ddagger \\
(.025)\end{array}$ & \\
\hline $\begin{array}{l}\text { Predicted wealth } \\
\text { differential }\end{array}$ & $\begin{array}{c}.00008 \\
(.00006)\end{array}$ & $\begin{array}{c}.00007 \\
(.00006)\end{array}$ & $\begin{array}{c}.00003 \\
(.00006)\end{array}$ & $\begin{array}{c}.00006 \\
(.00006)\end{array}$ & $\begin{array}{c}.00008 \\
(.00006)\end{array}$ & $\begin{array}{c}.00007 \\
(.00006)\end{array}$ & $\begin{array}{c}.00004 \\
(.00006)\end{array}$ \\
\hline $\begin{array}{l}\text { [one standard } \\
\text { deviation change] }\end{array}$ & {$[.012]$} & {$[.011]$} & {$[.005]$} & {$[.009]$} & {$[.012]$} & {$[.011]$} & {$[.006]$} \\
\hline \multicolumn{8}{|l|}{ Controls } \\
\hline $\begin{array}{l}\text { Family } \\
\text { structure }\end{array}$ & Yes & Yes & Yes & Yes & Yes & Yes & Yes \\
\hline Race/ Ethnicity & Yes & Yes & Yes & Yes & Yes & Yes & Yes \\
\hline City/Wards & Yes & Yes & Yes & Yes & Yes & Yes & Yes \\
\hline Observations & 2734 & 2734 & 2734 & 2734 & 2734 & 2734 & 2734 \\
\hline $\begin{array}{l}\text { Wald } \\
\text { chi-square }\end{array}$ & $535.4 \dagger$ & $545.9 \dagger$ & $562.7 \dagger$ & $544.6 \dagger$ & $541.8 \dagger$ & $575.1 \dagger$ & $595.9 \dagger$ \\
\hline Pseudo $\mathrm{R}^{2}$ & .26 & .26 & .27 & .26 & .26 & .27 & .28 \\
\hline
\end{tabular}

$\dagger$ implies $\mathrm{p}$-value $\leq .01 ; *$ implies $\mathrm{p}$-value $\leq .05 ; \ddagger$ implies $\mathrm{p}$-value $\leq .10$ 
Table 5: Poverty and adolescent labor force attachment for youth 14 to 16 years of age marginal effects from unweighted Probit regressions

\begin{tabular}{|c|c|c|c|c|c|c|c|}
\hline $\begin{array}{l}\text { Independent } \\
\text { variables }\end{array}$ & (1) & (2) & (3) & (4) & (5) & (6) & (7) \\
\hline $\begin{array}{l}\text { Household } \\
\text { wealth }<\$ 50\end{array}$ & $\begin{array}{l}.035^{*} \\
(.018)\end{array}$ & & & & & & \\
\hline $\begin{array}{l}\text { Household } \\
\text { wealth }<\$ 100\end{array}$ & & $\begin{array}{l}.075 \dagger \\
(.018)\end{array}$ & & & & & \\
\hline $\begin{array}{l}\text { VERY POOR } \\
\text { household }\end{array}$ & & & $\begin{array}{l}.091 \dagger \\
(.038)\end{array}$ & & & & $\begin{array}{l}.063 \neq \\
(.037)\end{array}$ \\
\hline $\begin{array}{l}\text { POOR } \\
\text { household }\end{array}$ & & & $\begin{array}{l}.095 \dagger \\
(.037)\end{array}$ & & & & $\begin{array}{l}.108 \dagger \\
(.043)\end{array}$ \\
\hline $\begin{array}{l}\text { NEAR POOR } \\
\text { household }\end{array}$ & & & $\begin{array}{l}.087 \dagger \\
(.024)\end{array}$ & & & & $\begin{array}{l}.076 \dagger \\
(.025)\end{array}$ \\
\hline $\begin{array}{l}\text { Home } \\
\text { Ownership }\end{array}$ & & & & $\begin{array}{l}-.043 \dagger \\
(.013)\end{array}$ & & & $\begin{array}{l}-.023 \\
(.016)\end{array}$ \\
\hline $\begin{array}{l}\text { Low status } \\
\text { occupation }\end{array}$ & & & & & $\begin{array}{l}-.004 \\
(.013)\end{array}$ & & \\
\hline $\begin{array}{l}\text { Occupation = } \\
\text { Laborer }\end{array}$ & & & & & & $\begin{array}{l}.005 \\
(.021)\end{array}$ & \\
\hline $\begin{array}{l}\text { Predicted wealth } \\
\text { differential } \\
\text { [one standard } \\
\text { deviation change] }\end{array}$ & $\begin{array}{c}-.0001 \dagger \\
(.00004) \\
{[-.015]}\end{array}$ & $\begin{array}{c}-.0001 \dagger \\
(.00005) \\
{[-.015]}\end{array}$ & $\begin{array}{c}-.0001 \dagger \\
(.00005) \\
{[-.015]}\end{array}$ & $\begin{array}{c}-.0001 \dagger \\
(.00005) \\
{[-.015]}\end{array}$ & $\begin{array}{c}-.0001 \dagger \\
(.00005) \\
{[-.015]}\end{array}$ & $\begin{array}{c}-.0001 \dagger \\
(.00005) \\
{[-.015]}\end{array}$ & $\begin{array}{c}-.0001 * \\
(.0004) \\
{[-.015]}\end{array}$ \\
\hline \multicolumn{8}{|l|}{ Controls } \\
\hline $\begin{array}{l}\text { Family } \\
\text { structure }\end{array}$ & Yes & Yes & Yes & Yes & Yes & Yes & Yes \\
\hline Race/ Ethnicity & Yes & Yes & Yes & Yes & Yes & Yes & Yes \\
\hline City/Wards & Yes & Yes & Yes & Yes & Yes & Yes & Yes \\
\hline Observations & 2734 & 2734 & 2734 & 2734 & 2734 & 2734 & 2734 \\
\hline $\begin{array}{l}\text { Wald } \\
\text { chi-square }\end{array}$ & $447.4 \dagger$ & $447.3 \dagger$ & $472.2 \dagger$ & $458.9 \dagger$ & $441.1 \dagger$ & $463.2 \dagger$ & $477.2 \dagger$ \\
\hline Pseudo $\mathrm{R}^{2}$ & .25 & .25 & .26 & .25 & .25 & .26 & .26 \\
\hline
\end{tabular}

